\title{
10 Het gebruik van elastische tapes
}

Voor het doelmatig gebruiken van preventieve en therapeutische verbanden is kennis over de werking en de geschiktheid van de verschillende verbandmaterialen en -typen een belangrijke voorwaarde. Het nut en daarmee ook het effect van therapieën met diverse verbanden worden wezenlijk beïnvloed door de verschillende fysische eigenschappen van kleefverbanden.

Elastische kleefverbanden zoals Tricoplast en Elastoplast zijn met name in de lengte rekbaar en kunnen daarom worden gebruikt bij uiteenlopende ziektebeelden en blessures van het bewegingsapparaat.

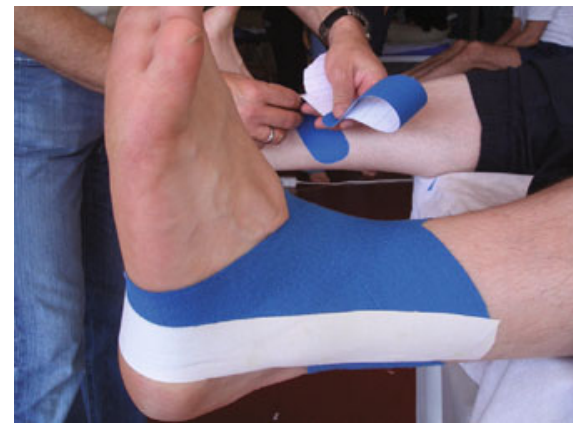

Combinatie van een klassieke, nietelastische tape (Leukotape) met elastische tape (Leukotape K)

Elastische kleefverbanden hebben een hoge mate van compressiewerking, zijn slipvast (grote kleefkracht), zijn eenvoudig afrolbaar en worden goed verdragen door de huid. Daarom kunnen ze ook enkele dagen worden gedragen. Ze zijn heel goed te combineren met een niet-elastische tape (Leukotape). Ook het gebruik van Leukotape K (100\% katoen, acrylaatkleefmiddel, elastisch) is bij veel blessures van het bewegingsapparaat geïndiceerd in een combinatie van elastische en niet-elastische verbanden of tapes.

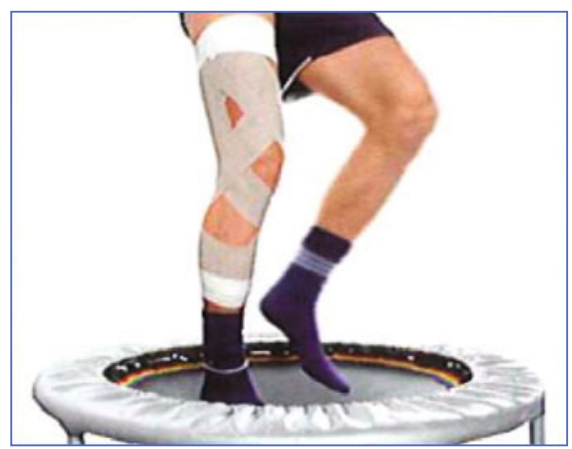

Combinatie van Tricoplast en Leukotape

\section{Elastische kleefverbanden - gebruik en tips}

- Elastisch kleefverband wordt, afhankelijk van de locatie en het toepassingsbereik, uitgerekt en dan aangebracht. De rekking van het verband bedraagt in de regel 25 tot $75 \%$. Nooit met maximale rekking en met sterke compressie op het weefsel aanleggen.

- Net als bij het niet-elastische tapen geldt ook hier: heldere indicatie en diagnose, functiecontrole van de geblesseerde structuren, inspectie en palpatie, controle van het functionele verband na het aanleggen, checks.

- Voor gesplitste Tricoplast-stroken moet het verband met een schaar worden ingeknipt. Daarna kan het kleefverband handmatig verder tot aan de gewenste lengte worden ingescheurd.

- Bij het in- en afscheuren het verbandmateriaal strak houden en niet in een hoek trekken. De ingescheurde verbanddelen altijd onder spanning houden.

- Bij het werken met elastisch kleefverband altijd de tijd nemen. De kleefstof niet met de vingers aanraken (alleen bij het prepareren en vasthouden van het verband).

- Tijdens het douchen elastische verbanden met plasticfolie afdekken (bij contact met water en vocht krimpt elastisch verband).

- Verband dat los is gaan zitten moet altijd worden vervangen, aangezien het anders zijn werking verliest.

- Vochtig geworden verband laten drogen (omwikkelen met ideaalverband mogelijk). 